\title{
Propaganda and Strategic / Social Communications: Features of Distinction and Actualization of Definition
}

\author{
Alla Hrebeniuk *[0000-0002-8703-3432], Olena Ufimtseva [0000-0001-9118-0016], \\ Valerii Horovyi [0000-0002-2644-5249]
}

National Academy of Security Service of Ukraine, Kyiv, Ukraine

*alla7997@meta.ua

\begin{abstract}
In the context of counteracting the hybrid war, targeting the Euro-Atlantic project as a whole, intensifying the fight against destructive propaganda and the need to build effective strategic communications as a mechanism for this fight, the issue of differentiating these concepts and clarifying their essence becomes relevant. The current legislation, available scientific and lexicographical works do not give an unambiguous answer about the peculiarities of propaganda, strategic / social communications. Therefore, the following are in demand: comprehensive study and generalization of all sources related to this issue; critical rethinking of the provisions developed by practitioners and scientists in this field; developing an unambiguous position on the cooperation of the terms «propaganda», «strategic communications», «social communications». In view of this, the article forms arguments in favour of distinguishing these terminological units, taking into account: the characteristics of destructive activities of propaganda, provided by the Strategy of the National Security of Ukraine, Criminal Code of Ukraine, Law of Ukraine «On Condemnation of Communist and National Socialist (Nazi) Totalitarian Regimes in Ukraine and Prohibition of Propaganda of Their Symbols», experts in the field of counteracting external aggression against Ukraine; strategic and social communications, localized by scientists in a constructive way. The results of the study made it possible to develop authorial definitions of these concepts, which correspond to the American approach to the definition of propaganda and strategic communications. Their further use will help synchronize domestic terminology with relevant terminology of the Euro-Atlantic community, develop coherent mechanisms for counteracting hybrid warfare and combating negative information influences.
\end{abstract}

Keywords: propaganda, strategic communications, social communications, improvement of terminological units, struggle against negative information influences, counteraction to hybrid war.

\section{INTRODUCTION}

The Strategy of the National Security of Ukraine, enacted by the Decree of the President of Ukraine on September 14, 2020 № 392/2020 (hereinafter - the Strategy), determines that destructive propaganda both outside and inside Ukraine, using social contradictions, incites hostility, provokes conflicts, undermines social unity. Paragraph 45 of the Strategy also defines propaganda as subversive. At the same time, the lack of a holistic information policy of the state, the weakness of the system of strategic communications complicate the neutralization of this threat [1].

We are convinced that the term «propaganda» is used in the current legislation in a purely negative context. Therefore, strategic communications are opposed to subversive and destructive [2]. propaganda. On the other hand, a number of researchers identify these two phenomena [3-5]. As a result, the heterogeneity of scientists and experts, as well as the ambiguity of the regulatory framework raises the issue of distinguishing between the concepts of strategic communications and propaganda.

\section{RESEARCH METHODOLOGY}

In the process of research we used the following methods:

- induction and deduction - to compare individual concepts (propaganda and strategic and social communications, «black», «grey» and «white» propaganda); 
- analysis and synthesis - in order to determine the categories of «propaganda», «strategic communications», "social communications», to clarify their essence and content;

- comparative studies - to research the state of consolidation of the phenomena we study in various regulations and scientific works;

- interpretation - for: formulation of concepts, improvement of the conceptual apparatus;

- comparative-legal method - in the analysis of the rules of law of Ukraine;

- logical-semantic - to clarify the conceptual apparatus, the essence of propaganda and strategic / social communications;

- structural-functional method - is one of the main in the systematic study of social phenomena and processes; is to divide a complex object into components, study the relationships between them and determine the place and role of all components in the functioning of the object as a whole.

In our opinion, the problem of delimitation of terminological units lies in the area of tasks of legal linguistics and legal terminology (is a specialized area of research of legal terminology, synthesizing modern methodological approaches of linguistics and legal sciences), as well as legal lexicography (within its limits the description and ordering of legal terminology is carried out). Only with a combination of linguistic and legal knowledge the nominative function of the language of jurisprudence is realized, enabling the correct naming of professional realities and concepts. The use of lexicographic sources and the application of the lexicographic method of research are important.

\section{RESULTS OF THE RESEARCH}

Strategic communications and propaganda are presented in one synonymous line by L. Rowland and S. Tatham. They note that for both propaganda and strategic communications, the desired result is the exertion of informational influence, for which identical tools can be used - mechanisms of public diplomacy, information operations, etc. [6]. Instead, D. Dubov and A. Barovska insist on their demarcation.

Types of propaganda are considered by V. Ostroukhov, V. Petryk, A. Kuzmenko, Yu. Levenets, O. Kholod. Partial, within these types, identification [7,8] of propaganda with strategic communications occurs in the works of N. Ivanova, O. Palyvoda, V. Strohyi, V. Koval.

M. Zakirov highlighted the role of strategic communications in the modern world, V. Medvedieva described strategic communications in providing scientific support of library and information activities, V. Palchuk studied the place of public libraries in development of strategic communications at the regional level, L. Chupryna demonstrated the features of information and analytical support of strategic communications, S. Kulytskyi concerned with the problems of analytical activities of the library as a means of identification, verification and positioning of strategic communications of the national economy. [9].

Propaganda is defined as a destructive phenomenon by the current legislation of Ukraine, experts and practitioners D. Tymchuk, Yu. Karin, K. Mashovets, V. Husarov. V. Pylypchuk, L. Kompantseva, I. Doronin, O. Dzoban, L. Pelepeichenko, and others considered strategic and social communications exclusively in a constructive way.

However, none of the well-known authors has clearly distinguished these concepts, which sometimes leads to their substitution, confusion of these different in importance phenomena, ambiguity in their use.

Therefore, in this publication we analyse both legal acts and scientific and lexicographic sources, which allows to establish the distinctive features of propaganda and social / strategic communications, to distinguish the terminological units that name them.

\section{DISCUSSION OF RESULTS}

According to the Great Explanatory Dictionary of the Modern Ukrainian Language, propaganda is: dissemination and constant, deep and detailed explanation of ideas, views, knowledge; ideological influence on the masses or certain groups of people, which is political or religious in nature [10, p. 1162]. As we can see, this definition is general and does not reveal the features of the distinction between the phenomena we study.

On the other hand, according to the Political Encyclopedia, there are the following types of propaganda, the definitions of which reveal more about the nature of propaganda:

«white» propaganda - its sources are open (provided with the use of information from official sources: the Office of the President, the Cabinet of Ministers of Ukraine) and accessible, implemented by persuasion, standard techniques of public relations (for example, through the media) and with one-sided guidance arguments, without masking of the real goals;

«grey» propaganda - its origin is veiled (the media of official channels can be used, but with concealment of its sources and reliable orientation), and the purpose is to impose false information on the addressee, to falsify facts and opinions;

«black» propaganda comes from a disguised source, denying the real origin of the content, aims to introduce mass consciousness into total deception [11, p. 27]. 
We make sure that the content of the «white» propaganda actually reflects the work of the «public relations service», which informs and gives a certain interpretation of events. That is, it can be identified with strategic communications. On the other hand, the Strategy of the National Security of Ukraine considers propaganda in the sphere of the «black» type.

In addition to this normative legal act, the Criminal Code of Ukraine also gives propaganda an exclusively negative connotation, establishing responsibility for:

Art. 436 «Propaganda of war» - public appeals to aggressive war or to the start of a military conflict, as well as the production of materials calling for such actions for the purpose of their distribution or distribution of such materials;

Art. 436-1 «Production, distribution of communist, Nazi symbols and propaganda of communist and National Socialist (Nazi) totalitarian regimes» production, distribution, and public use of symbols of communist, National Socialist (Nazi) totalitarian regimes, including souvenirs, public usage of anthems of the Union of Soviet Socialist Republics, Ukrainian Soviet Socialist Republic, other union and autonomous Soviet republics or their fragments throughout Ukraine, except as provided for in parts two and three of Article 4 of the Law of Ukraine «On Condemnation of Communist and National Socialist (Nazi) Totalitarian Regimes in Ukraine and Prohibition of Propaganda of Their Symbols» [12].

The Law of Ukraine «On Condemnation of Communist and National Socialist (Nazi) Totalitarian Regimes in Ukraine and Prohibition of Propaganda of Their Symbols» № 317-VIII of April 9, 2015 also localizes propaganda among destructive phenomena [13]

Experts D. Tymchuk, Yu. Karin, K. Mashovets, V. Gusarov also do not consider propaganda as a positive phenomenon. They consider it purely a tool in the arsenal of the aggressor country, which launched a hybrid war against Ukraine and made an act of aggression [14].

So, these regulations and practice indicate that propaganda is implemented mostly in the format of «black» or at least «grey» format of dissemination and constant, deep and detailed explanation of any ideas, views, knowledge.

In turn, we find that:

communication in general is a form of information exchange between the subjects of the social structure in order to realize their potential;

strategic communications are social communications that acquire strategic importance in view of their implementation between the actors of the security and defence sector and civil society [15].
Note that, according to L. Pelepeichenko, the term «strategic communications» should not be equated with the terminological unit «social communications». She argues that social communication is the mutual exchange of socially significant information by participants, which affects both the participants themselves and society as a whole. In turn, strategic communications are characterized by:

a focus on the key goals of the country as a whole or its institutions, industries;

social certainty;

planning;

realization in intergovernmental, interstate, interbranch interactions [16].

As you can see, these terms are not endowed with a negative connotation. Therefore, we cannot classify strategic and social communications as «black» or «grey» propaganda.

In support of our conclusions, D. Dubov and A. Barovska believe that the concepts of strategic communications and propaganda should not be considered synonymous. They suggest that in American terminology, propaganda is any form of hostile communication, especially biased or deceptive, aimed at influencing the thoughts, emotions, relationships, or behaviour of a group for profit (direct or indirect).

At the same time, these scientists note that the purpose of propaganda and strategic communications is the same - to influence the audience, and the difference is the focus on how information is presented to achieve influence: in the format of biased / misleading information for propaganda; based on reality and «communication by actions» (in the case of strategic communications) [17].

Thus, «white» propaganda, implemented in its own way, cannot be considered propaganda, because its content is more in line with the essence of strategic communications. In turn, «black» and «grey» propaganda is real propaganda, which, according to American experts, is a hostile mechanism of biased or deceptive communication.

\section{CONCLUSIONS}

This delineation of types of propaganda, their localization within the purely propaganda and separately strategic communications, makes it possible to determine that:

propaganda is the dissemination and constant, deep and detailed explanation of biased / misleading information from disguised sources in order to impose false information on the addressees, falsify facts and opinions, and introduce mass consciousness into total deception; 
strategic communications - is the dissemination and constant, deep and detailed explanation of ideas, views, knowledge, implemented between the security and defence sector and civil society, aimed at key goals of the country as a whole or its institutions, industries, characterized by social certainty, planning, implementation in intergovernmental, interstate, intersectoral interactions;

social communications is the dissemination and constant, deep and detailed explanation of socially significant ideas, views, knowledge in the format of mutual exchange of relevant information by the participants of communication.

Taking into account this approach, the classification of types of propaganda needs to be revised, including to it only its «black» and «grey» types, but removing the «white» type as inherent in strategic and social communications. This step will take into account the peculiarities of their delimitation and actual definition.

\section{REFERENCES}

[1] "Stratehiia natsionalnoi bezpeky Ukrainy, zatverdzhena Ukazom Prezydenta Ukrainy №392/202014 veresnia 2020 roku” [Strategy of the National Security of Ukraine, approved by the Decree of the President of Ukraine №392 / 2020 on September 14, 2020], available at: https://www.president.gov.ua/documents/3922020 $-35037$

[2] Ruyu Zheng, Kan Wu and Ru Li (2011), "Study on Overburden's Destructive Rules Based on Similar Material Simulation", IJMECS, vol. 3, no. 5, pp. 54-60, DOI: 10.5815/ijmecs.2011.05.08

[3] Korystin, Oleksandr and Svyrydiuk, Nataliia (2021), "Activities of Illegal Weapons Criminal Component of Hybrid Threats", Proceedings of the International Conference on Economics, Law and Education Research (ELER 2021), vol. 170, 22 March, pp. 86-91, DOI: 10.2991/aebmr.k.210320.016

[4] Kovalchuk, T.I. Korystin, O.Y. and Sviridyuk, N.P. (2019), "Hybrid threats in the civil security sector in Ukraine", Problems of Legality, vol. 147, pp. 163-175, DOI: $\quad 10.21564 / 2414-$ 990x.147.180550

[5] Tkachenko, Volodymyr Kwilinski, Aleksy Korystin, Oleksandr Svyrydiuk, Natalia and Tkachenko, Iryna (2019), “Assessment of information technologies influence on financial security of economy", Journal of security and sustainability issues, march, vol. 8, no. 3, pp. 375385, DOI: 10.9770/jssi.2019.8.3(7)
[6] Rowland, L. and Tatham, S. "Strategic Communication \& Influence Operations: Do We Really Get It?", available at: mercury.ethz.ch/serviceengine/Files/ISN/119385/ .../2010_08.pdf

[7] Sagar Shinde, Ritu Khanna and Rajendra Waghulade (2019), "Identification of Handwritten Complex Mathematical Equations", International Journal of Image, Graphics and Signal Processing, vol. 11, no. 6, pp. 45-53, DOI: $10.5815 /$ ijigsp.2019.06.06

[8] Dayanand G. Savakar and Anil Kannur (2019), "Hidden Markov Model for Identification of Different Marks on Human Body in Forensic Perspective", International Journal of Modern Education and Computer Science, vol. 11, no. 3, pp. 38-45, DOI: 10.5815/ijmecs.2019.03.06

[9] Naukovi pratsi Natsionalnoi biblioteky Ukrainy imeni V.I. Vernadskoho [Scientific works of the National Library of Ukraine named after VI Vernadsky] (2019), redkol.: V. Popyk (holova), H. Boriak, V. Horovyi [ta in.]; za zah. red. V. Horovoho ; vidp. red. N. Ivanova; NAN Ukrainy, Nats. b-ka Ukrainy im. V.I. Vernadskoho, Asots. B-k Ukrainy, vyp. 52: Rozvytok sotsialnoinformatsiinykh komunikatsii $\mathrm{v}$ umovakh informatyzatsii, Kyiv, Ukraine.

[10] Velykyi tlumachnyi slovnyk suchasnoi ukrainskoi movy [Large explanatory dictionary of the modern Ukrainian language] (2009), uklad. i holov. red. V.T.Busel, VTF "Perun", Kyiv, Irpin, Ukraine.

[11] Boiko, O.D. Propahanda. Politychna entsyklopediia [Propaganda. Political encyclopedia] / Redkol.: Yu.A. Levenets (holova), Yu.I. Shapoval (zast. holovy) ta in. Kyiv : Parlamentske vydavnytstvo, 2011. 610 s. [in Ukrainian].

[12] Kryminalnyi kodeks Ukrainy [Criminal Code of Ukraine], available at: https://zakon.rada.gov.ua /laws/show/2341-14\#Text

[13] Zakon Ukrainy «Pro zasudzhennia komunistychnoho ta natsional-sotsialistychnoho (natsystskoho) totalitarnykh rezhymiv $v$ Ukraini ta zaboronu propahandy yikhnoi symvoliky» № 317 VIII vid 9 kvitnia 2015 roku [Law of Ukraine «On Condemnation of Communist and National Socialist (Nazi) Totalitarian Regimes in Ukraine and Prohibition of Propaganda of Their Symbols»], available at: https://zakon.rada.gov.ua/laws/ show/317-19\#Text 
[14] Vtorzhenye v Ukraynu: Khronyka rossyiskoi ahressyy [Invasion into Ukraine: a chronicle of Russian aggression] (2016), Kyiv, Ukraine.

[15] Pylypchuk, V.H. Kompantseva, L.F. Kudinov, S.S. Doronin, I.M. Dzoban, O.P. Akulshyn, O.V. and Zaruba, O.H. Stanovlennia $i$ rozvytok systemy stratehichnykh komunikatsii sektoru bezpeky $i$ oborony Ukrainy [Formation and development of the system of strategic communications of the security and defence sector of Ukraine] (2018), monohrafiia, TOV «Vydavnychyi dim «ArtEk», Kyiv, Ukraine.

[16] Stratehichni komunikatsii v umovakh hibrydnoi viiny: pohliad vid volontera do naukovtsia
[Strategic communications in a hybrid war: a view from a volunteer to a scientist] (2018), monohrafiia, NA SB Ukrainy, Kyiv, Ukraine.

[17] Dmytro, Dubov and Anastasiia, Barovska (2018), Stratehichni komunikatsii na suchasnomu etapi: teoretyko-kontseptualni problemy rozuminnia ta skladnoshchi praktychnoi realizatsii. Stratehichni komunikatsii $v$ umovakh hibrydnoi viiny: pohliad vid volontera do naukovtsia [Strategic communications in a hybrid war: a view from a volunteer to a scientist], monohrafiia, NA SB Ukrainy, Kyiv, Ukraine. 